\title{
Karşılıklı Bağımlılık Teorisi Açısından Türkiye-İran Ekonomik İlişkileri: 2002-2014
}

\author{
Abdüssamet Pulat
}

\section{Öz}

Türkiye ve İran arasında 1990'lı y1larda yaşanan olumsuzluklar ve krizler 2000'li yılların başında yerini yumuşamaya bırakmıştır. 2002 yılında Türkiye'de iktidara gelen AK Parti döneminde ise iki ülke arasındaki ilişkiler oldukça derinleşmiştir. Gelişen bu ilişkilerin en önemli taraflarından biri ise Türkiye ve İran arasındaki ekonomik ilişkilerin geldiği seviye olmuştur. Türkiye'nin yeni diş politika uygulamalarından olan karşılıklı ekonomik bağımlılık oluşturma hedefi sayesinde diğer komşuları ile birlikte İran ile de ekonomik ilişkileri tarihinin en iyi seviyesini görmüştür. Bu çalışma Türkiye ve İran arasındaki ekonomik ilişkileri Joseph S. Nye ve Robert O. Keohane'nin 1980'lere doğru ortaya koydukları karşılıklı bağımlılık kuramı açısından ele almaktadır. Çalışmada, Türkiye'nin İran'a yönelik karşılıklı ekonomik bağımlılık kurma hedefinin iki ülke ticaretinin hala düşük miktarlarda olması ve bölgesel rekabetin getirdiği güven sorunu nedeniyle başarısız olduğu sonucuna ulaşılmıştır. Ayrıca İran'a yönelik uluslararası yaptırımların iki ülkenin enerji politikalarında iş birliğine gitmelerini engelleyen önemli bir faktör olduğu tespit edilmiştir.

Anahtar Kelimeler: Türkiye, İran, Ekonomik İlişkiler, Karşılıklı Bağımlılık

Sakarya Üniversitesi Ortadoğu Enstitüsü Doktora Öğrencisi ve Araştırma Görevlisi, apulat@sakarya.edu.tr 


\title{
Turkey and Iran Economic Relations From the Perspective of Interdependence Theory: 2002-2014
}

\author{
Abdüssamet Pulat*
}

\begin{abstract}
Adversities and crises in the 1990s between Turkey and Iran has left to soften its place at the beginning of the 2000s. In 2002, during the AK Party came to power in Turkey, relations between the two countries rather deepened. Developing one of the most important aspects of this relationship has been the level at which the economic relations between Turkey and Iran. Turkey's target is to create economic interdependence in economic relations with Iran, along with other neighbors that the new administration's foreign policy has seen the best level in history. This study discusses economic relations with Joseph S. Nye and Robert O. Keohane in terms of the interdependence between theory put forward towards 1980, which is one of the best examples of the conversion in foreign policy, Turkey and Iran. Turkey's goal of establishing trade of the two countries for mutual economic dependence concluded that Iran has still failed because of the lack of trust in the regional competition to be brought in small amounts. It has also been determined that international sanctions against Iran are an important factor preventing the two countries from going to business associations in energy politics.
\end{abstract}

Keywords: Turkey, Iran, Economic Relations, Interdependence

PhD Student, Sakarya University Middle East Institute, apulat@sakarya.edu.tr 


\section{Giriş $^{1}$}

Ekonomik ve demografik büyüklükleri ile Ortadoğu'nun iki bölgesel gücü olan Türkiye ve İran, tarihsel ve kültürel bağlarıyla kökü çok eskiye dayanan komşuluk ilişkilerine sahiptir. Geçmişte zaman zaman savaşlarla sonuçlanan bölgesel rekabetin ardından 1. Dünya Savaşıyla birlikte y1kılan Osmanlı İmparatorluğu'nun yerine kurulan Türkiye Cumhuriyeti ve iki yıl sonra İran'da kurulan Pehlevi Hanedanlığı döneminde iki ülke ilişkileri için yeni bir sayfa açılmıştır. Bu yeni dönemde hem İran hem de Türkiye'de kurulan rejimlerin çağdaş bir ülke olma hedefi, iki ülkenin, geçmişin aksine iyi komşuluk ilişkileri kurmasına vesile olmuştur. Ancak 1979 yılında İran'da gerçekleşen İslam Devriminin ardından iki ülke yönetimleri arasında ortaya çıkan ideolojik farlılıklar ilişkilerin seyrini negatif yönde etkilemeye başlamıştır. İdeolojik faktörlerin yanı sıra 1980'lerin ortasında başlayan ve 1990'larda Türkiye'nin en önemli sorunu haline gelen PKK terörü de Türkiye-İran ilişkilerini belirleyen diğer bir faktör olmuştur. 1990'ların sonlarına doğru yaşanan bazı kırılmalar 2000'li yıllarda ilişkilerin düzelmesi için zemin hazırlamış ve özellikle 2002 yılında Türkiye'de iktidara gelen AK Parti döneminde iki ülke arasında iyi ilişkiler kurulmaya başlanmıştır.

Bu dönemde kurulan iyi ilişkilerin altında yatan en önemli faktör, AK Parti hükümetinin özellikle Türkiye'nin komşularıyla 1990'lar boyunca sorunlu olan ilişkileri düzelterek iş birliğine dayalı yeni ilişkiler kurmak istemesidir. 'Komşularla sıfır sorun' politikası olarak adlandırılan bu yeni politikanın en önemli aracı ise ekonomi olmuştur. Kalabalık iş adamlarıyla yapılan ülke ziyaretleri, yabancı sermayenin Türkiye'ye girmesi için sağlanan kolaylıklar, ülkelerle karşılıklı vizelerin kaldırılması, yabancı iş adamlarıyla düzenlenen iş forumları ve serbest ticaret anlaşmaları bu politikanın uygulamadaki göstergeleridir. Dış politika yapıcılarının bu politikaları uygulamadaki en önemli hedefi ise özellikle Türkiye'nin komşularıyla karşılıklı ekonomik bağımlılık yaratarak siyasi ilişkilerin ekonomik ilişkileri değil ekonomik ilişkilerin siyasi ilişkileri pozitif yönde etkilediği bir istikrar havzası oluşturmak olmuştur.

Bu çalışma Türkiye-İran Enerji İlişkileri başlıklı yüksek lisans tezimden türetilmiştir. (Bknz. Türkiye-İran Enerji İlişkileri, yayınlanmamış yüksek lisans tezi, Marmara Üniversitesi, Ortadoğu Araştırmaları Enstitüsü 
Türkiye ve İran arasındaki ekonomik ilişkiler bu politikaların sonuçlarının göründüğg̈ en açık örneklerinden biridir. 1990'dan 2000 yılına kadar iki ülke arasındaki ticaret hacmi sadece 1996 yılında 1 milyar doları geçerken 2000'li yıllarda bu rakam hızla artmış ve 2014 yılına gelindiğinde bölgedeki istikrarsızlığa ve nükleer faaliyetleri nedeniyle İran'a uygulanan yaptırımlara rağmen yaklaşık 14 milyar dolar seviyesine çıkmıştır.

Türkiye ve İran arasındaki ekonomik ilişkilerin bu kadar hızlı bir şekilde gelişme göstermesi iki ülke için de önemli bir kazanç olsa da bu ilişkinin ekonomik olarak bir karşılıklı bağımlılık oluşturduğu söylenemez. Zira yaklaşık 80 milyon nüfusa ve önemli bir ekonomik büyüklüğe sahip bu iki ülke arasında 14 milyar dolar seviyesindeki ticaret hacminin, potansiyelinin altında olduğu görülmektedir. Buna ek olarak Türkiye ve İran arasındaki ticaretin detaylarına inildiğinde, özellikle ekonomik olarak büyüdükçe enerji talebi artan Türkiye'nin İran'dan yaptığı yüksek miktarda doğalgaz ve petrol ithalatının kritik bir önemi olduğu görülmektedir. Dolayısıyla iki ülke arasındaki ticarette mal çeşitliliğinden ziyade enerji ithalatının ağırl1ğ1 vardır. Türkiye'nin İran'a olan ihracatı da önemli miktarlarda artış gösterse de ihracata konu olan mamullere bakıldığında demir-çelik ve değerli maden türü kolay ikame edilebilir malların olduğunu görüyoruz. İki ülke arasında ekonomik bir karşılıklı bağımlılığın olmamasının bir diğer göstergesi karşılıklı yatırımların az olmasıdır. Türkiye'ye gelen yabancı yatırımlar içinde İranlı yatırımcıların payı oldukça düşük kalırken İran'da yatırım yapan Türklerin de sayısı azdır. Ekonomik nedenlere ek olarak iki ülke arasında özellikle Arap Ayaklanmalarının ardından başlayan güç mücadelesi ve ABD'nin İran'a uyguladığı yaptırımlar karşılıklı ekonomik bağımlılığ engelleyen siyasi faktörlerdir.

Türk Dış Politikasının 2000'lerde geçirdiği dönüşüm ve özellikle ekonomik araçlara önem vermesi bu konudaki çalışmaların sayısını da artırmıştır. 2009 yılında yayınlanan makalesinde Kemal Kirişçi, Türkiye'nin 1990'larda Ortadoğu ve Kıbrıs'a yönelik dış politikası ile 2002 yılının ardından uyguladığı politikaları karşılaştırarak, 2002 yılının ardından Türkiye'nin yumuşak güç unsurlarını devreye soktuğunu ve özellikle ekonomik araçların dış politikada daha fazla kullanılmaya başladığını vurgulamıştır. Kirişci, Richard Rosecrance'nin “ticaret devleti” kavramından hareketle ekonomik araçların Türk dış politikasında başarılı bir şekilde kullanıla- 
rak Türkiye'nin bir ticaret devleti haline geldiğini iddia etmiştir. ${ }^{2}$ Mustafa Kutlay ise Türk dış politikasındaki dönüşüm ve bu dönüşümde ekonomik araçların yeri ve başarısı üzerine çalışmalar yapmıştır. Kutlay, Türk dış politikasının ekonomi politiği üzerine yaptığı çalışmada; Türkiye ekonominin kapsamlı bir sanayi stratejisinin olmaması, dış ticaretin sürekli ve artan bir şekilde açık vermesi ve bazı toplumsal sorunlar nedeniyle ekonomik araçların dönüştürücü kapasiteye sahip olmadığını iddia etmiştir. Kutlay, bu düşüncesine örnek olarak, Arap Baharı sonrası bölgede yaşanan krizlerde Türk Dış Politikasının etkisiz kalmasını göstermiştir. ${ }^{3}$ Kutlay, Osman Bahadır Dinçer ile yaptığı bir başka çalışmada, Türkiye'nin son dönemde yakaladığ1 ekonomik büyüme ve dış politikada kullandığı yumuşak güç unsurlarının Türkiye'yi bölgesinde potansiyel bir güç haline getirdiğini vurgulamıştır. Ancak diplomatik, ekonomik ve yumuşak güç unsurları açısından bakılırsa, her ne kadar Türkiye potansiyel bir güç olsa da düzen kurucu bir aktör olabilmesi için bu güç unsurlarının taşıdığı potansiyel yeterli değildir. ${ }^{4}$ Konuya ilişkin bir başka makalede Fatma Sarıaslan ise 2000'li y1llarda Türkiye ekonomisindeki büyüme ve Türkiye'nin dış politikada ekonomik araçları kullanarak ticaret hacmini artırmasını "ticaret devleti" perspektifinden ele almıştır. Sarıaslan, Türkiye ve İran arasında 2000'li y1llarda rekor seviyelere çıkan ticaret hacmini Türkiye'nin bir ticaret devletine dönüşmesinin göstergesi olarak yorumlamıştır. ${ }^{5}$ Mustafa Aydın ve Damla Aras, 2004 yılında yayınlandıkları makalelerinde Ortadoğu ülkelerindeki otoriter rejimler nedeniyle, bu ülkelerle girilen ekonomik ilişkilerde siyasi ilişkilerin belirleyici bir rol oynadığını savunmaktadırlar. Bu durumu Türkiye'nin İran, Suriye ve Irak ile olan ilişkilerini örnek vererek açıklamışlar ve Türkiye'nin bu ülkelerle olan ekonomik ilişkilerinin, siyasi ilişkilere bağımlı olarak seyrettiğini belirtmişlerdir. ${ }^{6}$ Kadri Kaan Renda ise

Kemal Kirişçi, The Transformation of the Turkish Foreign Policy: The Rise of the Trading State, New Perspectives on Turkey, no.40, 2009

3 Mustafa Kutlay, Yeni Türk Dış Politikasının Ekonomi Politiği: Eleştirel Bir Yaklaşım, Uluslararası İlişkiler Dergisi, cilt 9, say 35, Güz 2012

4 Mustafa Kutlay, Osman Bahadır Dinçer, Türkiye'nin Ortadoğu'daki "Bölgesel Güç" Potansiyeline İlişkin Ampirik Bir İncleme, USAK, Rapor no. 12-03, 2012 http://www. usak.org.tr/dosyalar/rapor/5GMcs3mKfFPCbD08MCXSSs6sfdvvA7.pdf, Erişim Tarihi: 18.04.2014

5 Fatma Sarıaslan, 2000'li Yıllarda Türkiye-İran Ekonomik İlişkileri, Akademik Ortadoğu Dergisi, Say1 14, İstanbul

6 Mustafa Aydın ve Damla Aras, Ortadoğu'da Ekonomik İlişkilerin Siyasi Çerçevesi; 
Türk dış politikasındaki dönüşümü Nye ve Keohane'nin "karmaşık karş1lıklı bağımlılık" teorisi açısından incelemiştir. Renda, Türkiye'nin komşularıyla olan ekonomik ve siyasi ilişkilerdeki gelişmeleri karmaşık karşılıklı bağımlılık yaratma çabası olarak yorumlamıştır. ${ }^{7}$ Bayram Sinkaya, 2000'li yıllarda Türkiye-İran ilişkilerindeki dönüşümü incelediği çalışmasında, Irak üzerindeki düşünceleri, teröre karşı işbirliği, doğalgaz ticareti gibi etkenlerin iki ülke siyasi ve ekonomik ilişkilerini geliştirdiğini ancak 2011 yilında başlayan Suriye'deki iç savaşın da gösterdiği gibi bölgesel rekabetin iki ülke ilişkilerindeki çatışma potansiyelini devam ettirdiğini belirtmiştir. ${ }^{8}$

Yapılan çalışmalarda daha çok, geçmiş yıllara oranla Türkiye'nin artan ticaret ağına ve hacmine odaklanılmış ancak bunun karşılıklı ekonomik bağımlılık yaratacak seviyede olup olmadığ 1 konusu üzerinde durulmamıştır. Türk Dış Politikasındaki dönüşüme ve bu dönüşümde ekonomik araçların ya da ticaretin öneminin vurgulandığı bu çalışmada; Türkiye-İran ilişkileri özelinde dış politikada belirlenen hedeflere ulaşılıp ulaşılmadığı araştırılmaktadır.

\section{Karşılıklı Bağımlılık Teorisi}

İkinci Dünya Savaşı'ndan sonra uluslararası siyaseti anlamada başat yaklaşım olan realist teoriye 1970'li yıllarda Joseph S. Nye ve Robert O. Keohane gibi isimler teorik düzlemde meydan okumuştur. Disiplinin temel tartışma konularından olan aktör, güç ve uluslararası sistem gibi konularda realistlerin görüşlerine karşı çıkan Nye ve Keohane, 1977 yılında yazdıkları Power and Interdependence (Güç ve Karşılıklı Bağımlılık) adlı kitaplarında "Karşı1ıklı Bağımlılık Teorisini”" ortaya atmışlardır."

Keohane ve Nye, bağımlılı̆̆ herhangi bir devletin davranışlarının dış bir güç tarafından belirlendiği ya da etki altına alındığı bir durum olarak ta-

Türkiye'nin İran, Irak ve Suriye ile Bağlantıları, Uluslararası İlişkiler Dergisi, Cilt 1, Say1 2, 2004

7 Renda, Kadri Kaan, Turkey's Neighborhood Policy: An Emerging Complex Interdependence?, Insight Turkey, vol.13, no.1, 2014

8 Bayram Sinkaya, Rationalization of Turkey-Iran Relations: Prospects and Limits, Insight Turkey, vol. 14, no. 2, 2012, pp. 137-156

9 Robert O. Keohane, Joseph S. Nye, Power and Interdependence, 2. Bask1, Tbs, 1989, s. 3, Christian Reus-Smit, Uluslararası İlişkiler Teoriler, Çev. Ali Aslan, M. Ali Ağcan, Küre Yay. 2.bask1, İstanbul 2013, s. 280 
nımlarken, dünya politikasındaki karşılıklı bağımlılı̆g devletlerin ya da aktörlerin karşılıklı olarak birbirlerini etkilediği ve dolayısıyla bağımlılığın karşılıklı bir hale gelmesi durumu olarak tanımlamışlardır. Dünya politikasındaki dönüşümü üç temel etken üzerinden anlatan Keohane ve Nye, özellikle ekonomik süreçlerin uluslararası sistemde yarattığ 1 değişikliğe vurgu yapmışlardır. Ulaşım ve iletişim teknolojilerindeki müthiş gelişme ile birlikte uluslararası ticaret daha hızlı artmaya başlamış ve bu da ülkeler arasındaki bağlantıları artırmıştır. Ticaretin daha kolay olmasının yanı sıra toplumların hayat standartlarının yükseltilmesi noktasında devletlerden talepleri artmış ve bu nedenle ülkelerin milli gelirlerinin artırılması hükümetlerin öncelikli hedefi olmuştur. Uluslararası sermeye ve işçi hareketlerinin artması, finans piyasalarının genişlemesi karşılıklı bağımlılığı artıran üçüncü ekonomik etken olmaktadır. ${ }^{10}$

Uluslararası sistemde karşılıklı bağımlılı̆g 1 oluşturan en önemli etken aktörler arasında oluşan bağlantıların kopması durumunda karşılaşılan maliyettir. Buna örnek olarak kullandığı petrolün tamamını bir başka ülkeden ithal eden bir ülke ile lüks tüketim eşyalarını ithal eden bir ülkeyi karşılaştırarak anlatan Keohane ve Nye, ilk ülkenin durumunun karşılıklı bağımlılık, ikincisinin ise maliyet söz konusu olmadığı için karş1lıklı bağl1lık olduğunu savunmuşlardır. ${ }^{11}$ Bununla birlikte karşılıklı bağımlılık konusunda bilinmesi gereken diğer bir konu ise aktörler arasındaki karşılıklı bağımlılık durumunun eşit olmayabileceğidir. Bu durum aktörler arasında asimetrik bir ilişki yaratır ve daha az bağımlı olan aktör pazarlık gücünü eline geçirerek diğer aktörün davranışlarını etkileyebilir. ${ }^{12}$ Keohane ve Nye bu asimetrik ilişkinin uluslararası sistemde gücü oluşturan etkenlerden biri olabileceğini iddia etmektedirler. Asimetrik karşılıklı bağımlılığın gücü nasıl yarattığını ise hassasiyet (sensitivity) ve kırılganlık (vulnerability) kavramlarıyla açıklamışlardır. ${ }^{13}$

Hassasiyeti bir aktörün olumsuz bir gelişme durumunda karşısına çıkan maliyetten etkilenme derecesi olarak tanımlayan Keohane ve Nye, buna

10 Keohane ve Nye, a.g.e, s.39-40, Joseph S. Nye, Robert O. Keohane Transnational Relations and World Politics: An Introduction, International Organization, vol. 25, no. 3, s. 332, pp. 329-349

11 Keohane ve Nye, a.g.e, s. 8-9

12 Keohane ve Nye, a.g.e, s. 11

13 Keohane ve Nye, a.g.e, s.11 
örnek olarak ise 1973 Petrol Krizi'nin ardından yükselen petrol fiyatları karşısında ABD, Japonya ve Batı Avrupa ülkelerinin durumunu göstermişlerdir. ABD'nin petrol ithalatının Japonya ve Batı Avrupa'dan daha düşük olması, fiyatlara karşı ABD'yi daha az duyarlı hale getirmektedir. Dolayısıyla petrol üreticisi ülkeler petrolü bir güç kaynağı olarak kullanabilir ancak ülkelerin hassasiyet düzeyleri bu etkinin derecesini belirleyen bir faktördür. ${ }^{14}$

Karşı1ıklı bağımlılıkta sadece hassasiyet faktörünün kullanılması durumunda bazı politik yönlerin gözden kaçırılmasına neden olacağını savunan Keohane ve Nye, bunun yanında kırılganlığın da karşılıklı bağımlılık ve güç arasındaki ilişkiyi etkileyen bir diğer faktör olduğunu belirtmişlerdir. Örneğin petrol ithalatı eşit oranda olan iki ülkeden birinin iç üretimini artırması, karşılaştığı maliyeti ve dolayısıyla fiyatlar karşısındaki kırılganlığını azaltacaktır. Keoahne ve Nye bu durumu 1960'ların sonunda yabancı spekülatörlerin politikaları ve merkez bankalarının dolar ve sterlin üzerindeki kararları karşısında zor durumda kalan ABD ve İngiltere'yi örnek vererek açıklamışlardır. ABD'nin politika değişikliğine gitmesi bu zor durum karşısında onun kırılganlığını azaltırken İngiltere'nin değişiklik yapamaması kırılganlık düzeyini devam ettirmiştir. ${ }^{15} \mathrm{Bu}$ durumda karş1lıklı bağımlılık ve güç ilişkisi incelendiğinde kırılganlığın hassasiyetten daha önemli bir güç kaynăğ olduğu iddia edilmektedir. Çünkü herhangi bir aktörün kendisini zor durumda bırakan bir duruma karşı politikalarını değiştirebilme gücü yani kırılganlığını azaltması hassasiyet derecesini de etkileyecektir. ${ }^{16}$ Sonuç olarak karşılıklı bağımlılık aktörlerin birbirlerinin politikalarını etkileyebilmesini sağlayan bir güç kaynağı olarak ortaya çımaktadır. Değişik şartlar altında bu gücü doğuran bazen duyarlılık olurken bazen de kırılganlık düzeyi olabilmektedir. ${ }^{17}$

Ülkeler arasındaki bağlantıların artmasıyla oluşan karşılıklı bağımlılık durumu devletleri iş birliğine daha fazla yöneltmektedir. Çünkü bu bağımlılık durumunun yarattığı hassasiyet ve kırılganlık bir maliyet doğurur ve ülkelerin askeri güç kullanması onları bu maliyetle karşı karşıya bırakır. Joseph

\footnotetext{
Keohane ve Nye, a.g.e, s.12

Keohane ve Nye, a.g.e, s. 13

Keohane ve Nye, a.g.e, s. 15

Keohane ve Nye, a.g.e, s.18
} 
S. Nye bu durumu ABD'nin Uzak Doğu politikasını örnek vererek anlatır. Hızlı ekonomik büyümesiyle dünya politikasındaki etkinliğini artıran Çin'e karşı ABD'nin çevreleme politikası uygulaması gerektiği düşüncesine karşı çıkan Nye, Soğuk Savaş döneminde ABD'nin hiçbir ekonomik ve sosyal bağı olmadığı SSCB'ye karşı uyguladığı politikayı bugün yüksek ticaret hacmi ve sosyal ilişkilerinin olduğu Çin'e uygulamasının yanlış olacağını vurgulamaktadır. Çin'i çevrelemenin ilerde ABD'ye bir düşman kazandıracağını düşünen Nye, bunun yerine Çin'in başat bir güç olmasından endişelenen komşularıyla iyi ilişkiler kurarak bölgede bir güçler dengesi yaratılmasını önermektedir. Bunun yanında Çin ve ABD arasındaki ticari ve sosyal bağlantılar göz önünde bulundurularak onunla iş birliği yapılma11 ve böylece gelecekte karşılaşılacak bir çatışmanın önüne geçilmelidir. ${ }^{18}$ Nye'ın verdiği bu örnekten de anlaşılacağı üzere aslında karşılıklı bağıml1lık durumu ülkeler arasında çatışmadan uzak, daha istikrarlı ilişkilerin kurulmasını sağlamaktadır.

\section{Türk Dış Politikası ve Karşılıklı Bağımlılık}

1990'lı yıllar Türkiye'nin iç sorunlarının dış politikasını fazlasıyla etkilediği yıllar olmuştur. PKK'nın artan eylemleri nedeniyle güvenlik ağırlıklı bir dış politika izleyen Türkiye'nin, hem komşularıyla hem de uluslararası aktörlerle kurduğu ilişkilerde güvenlik konusu öncelik taşıyordu. Irak'ın kuzeyindeki PKK yapılanmasına düzenlenen operasyonlar, 1998 yılında yine PKK'ya destek olması nedeniyle Suriye ile savaşın eşiğine gelinmesi, PKK faktörünün yanı sıra Türkiye-İran ilişkilerinde kendini gösteren ideolojik farklılık 1990'lı yıllarda iç sorunların dış politikadaki tezahürleri olarak ortaya çıkmıştır. ${ }^{19}$

Ancak 2000'lere yaklaşırken yaşanan bazı gelişmeler bu tablonun değişmesini sağlamıştır. 1999 yılında PKK lideri Abdullah Öcalan'ın yakalanarak Türkiye'ye getirilmesi, aynı yıl Suriye ile imzalanan Adana Protokolü ile bu ülkeyle başlatılan iyi ilişkiler uzun yıllardır devam eden güvenlik ağırlıklı politikanın değişmesi için zemin hazırlamıştır. ${ }^{20}$ Yine 1999 yı-

18 http://www.nytimes.com/2013/01/26/opinion/work-with-china-dont-contain-it.html? $\mathrm{r}=0$, Erişim tarihi: 15.10 .2014

19 MÜSİAD, Araştırma Raporları, Yükselen Değer Türkiye, İstanbul 2010, s.170

20 MÜSİAD, s. 170 
lındaki Helsinki Zirvesinde Türkiye'nin AB'ye aday ülke ilan edilmesi Türkiye'nin iç ve dış politikasında bazı değişiklikleri beraberinde getirmiştir. Helsinki sürecinden sonra asker-sivil ilişkilerinin düzenlenmeye başlaması ile TSK'nın dış politikada 1990'lı yıllar boyunca devam eden ağırlığı azalmaya başlamıştır. Siyaseti etkileyen bu gelişmelerin yanı sıra 2001 yılında yaşanan ekonomik kriz de Türkiye'nin ekonomi politikalarını değiştirmeye zorlamış ve dış ticarete daha fazla önem verilmeye başlanmıştır. 1999-2002 yıllarında iktidarda olan DSP-MHP-ANAP hükümeti döneminde dış politikada görülmeye başlanan değişim 2002 yılında tek başına iktidara gelen AK Parti hükümeti döneminde ise daha fazla belirginleşmiştir. $^{21}$

AK Parti hükümetinin ilk dönemlerinde dış politika danışmanı ve 2009 y1lından itibaren de Dışişleri Bakanı olan Ahmet Davutoğlu'nun "Stratejik Derinlik" isimli kitabında ortaya koyduğu görüşlere uygun olarak Türkiye'nin dış politikasının yeniden belirlendiği bir döneme girilmiştir. Kitabında Türkiye'nin bölgesindeki ilişkilerinin köklü bir değişim geçirmesi gerektiğini ${ }^{22}$ belirten Davutoğlu döneminde Türkiye bölgedeki etkinliğini artırmaya başlamıştır. Bunu yaparken 1990'lı yılların aksine güvenliği önceleyen bir politika yerine ekonomik ve kültürel unsurları ön plana alan bir politika geliştirmiştir. ${ }^{23} 1998$ yılında savaşın eşiğine gelinen Suriye ile 2009 yılında karş11ıklı olarak vizelerin kaldırılması ve serbest ticaret anlaşmalarının yapılması, Lübnan'daki hükümet krizlerine müdahil olunması, Kuzey Irak Bölgesel Yönetimi ile girilen iyi ilişkiler bu dönüşümün en somut örnekleridir. ${ }^{24}$ Türkiye'nin komşularıyla ilişkilerinin gelişmesi ve etkinliğinin artması yolunda ekonomiyi önemli bir araç olarak gören Davutoğlu döneminde Türkiye'nin Ortadoğu'ya yönelik dış politikasının en önemli hedeflerinden biri karşılıklı ekonomik bağımlılık yaratılarak Türkiye'nin etkinliğini artırmak ve komşularla daha sağlam ilişkiler kurmak olmuştur. ${ }^{25} \mathrm{Bu}$ dönemde gözlemlendiği üzere yurt dış seyahatlerinin

21 Kadri Kaan Renda, Turkey's Neighborhood Policy: An Emerging Complex Interdependence?, Insight Turkey, Vol. 13/NO.1, 2014, pp. 95-96

22 Ahmet Davutoğlu, Stratejik Derinlik, Küre Yayınları, 35. Bask1, İstanbul 2009, s. 142

23 Mustafa Kutlay, Yeni Türk Dış Politikasının Ekonomi Politiği: Eleştirel Bir Yaklaşım, Uluslararası İlişkiler Dergisi, cilt 9, say 35, Güz 2012, s. 102

24 MÜSİAD, s. 168

25 Fatma Sarıslan, 2000'li yıllarda Türkiye-İran Ekonomik İlişkileri, Akademik Ortadoğu Dergisi, Say1 14, s.66 
kalabalık iş adamları heyetleriyle yapılması, ülkelerle serbest ticaret anlaşmaları yapılması, karşı1ıklı olarak vizelerin kaldırılarak ilişkilerin geliştirilmeye çalışılması ve yabancı yatırımları çekmek için teşviklerin verilmesi bu amaca yönelik uygulanan politikalardır. Bu politikalar özellikle 2005 y1lından sonra sonuç vermeye başlamış ve Türkiye'nin ticaret hacminde Avrupa Birliği’nin payı azalırken Yakın ve Ortadoğu ülkelerinin payı artmaya başlamıştır.

Şekil 1: Türkiye'nin AB-Yakın ve Ortadoğu Ülkeleriyle Yaptığı Ticaretin Karşılaştırması

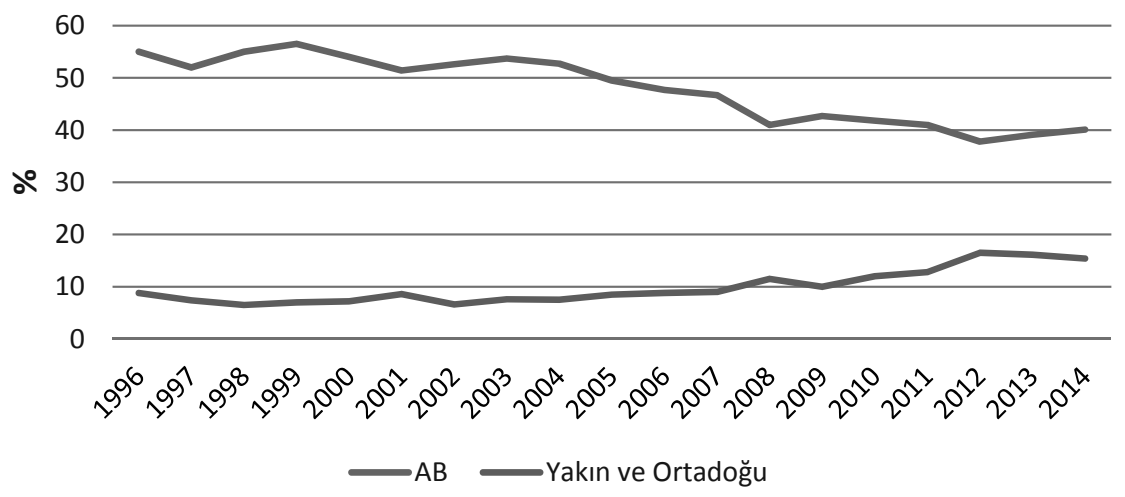

Kaynak: TÜiK

Şekilde de görüleceği üzere 1996 yılında Türkiye'nin toplam ticaretinde Avrupa Birliği üyesi ülkelerin pay1 \% 50'den fazla iken 2003 y1lında düşüşe geçmiş ve 2005 y1lında \% 50'nin altına düşmüştür. 2014 yılı sonu itibariyle $\% 40$ olarak gerçekleşen $\mathrm{AB}$ ülkelerinin toplam ticaret hacmindeki payına karşılık Yakın ve Ortadoğu ülkelerinin payı ise 1996 yılında \% 8 iken 2005 y1lından sonra artmaya başlamış ve 2014 yılına gelindiğinde \% 15,5 seviyesine yükselmiştir.

Türkiye'nin komşularıyla ekonomik ilişkileri geliştirmeye yönelik politikalarının ardından Irak, Suriye, Yunanistan ve Bulgaristan gibi komşularıyla olan ticaret hacimleri rekor seviyelere çıkmıştır. Örneğin 1996 yılında 220 milyon dolar olan Irak ile Türkiye arasındaki ticaret 2014 yılında 
bölgedeki tüm çatışmalara rağmen 11,1 milyar doları olarak gerçekleşmiş, bunun yanında Türkiye'nin ihracatında Irak, Almanya'dan sonra ikinci s1raya yükselmiştir. 1996 yılında Türkiye'nin bu dört komşusuyla ticareti 1,5 milyar doları civarında iken 2014 yılında 20 milyar doları geçmiştir. Türkiye'nin komşularıyla olan ticaretindeki bu artışın en net görüldügüü ülkelerden bir tanesi hali hazırda en yüksek ticaret hacminin olduğu İran'dır.

\section{Türkiye-İran Ekonomik İlişkileri}

Türkiye, 2014 y1lı sonu itibariyle 800 milyar dolar GSMH ile dünyanın en büyük 20 ekonomisi arasında yer alırken İran, ekonomisinin temelini oluşturan enerji sektörüne uygulanan yaptırımlara rağmen 406 milyar do$1 \mathrm{lar}^{26} \mathrm{GSMH}$ 'ye sahiptir. Bu ekonomik kapasitelerinin yanı sıra demografik büyüklükleri, askeri kapasiteleri ve tarihi birikimleriyle Ortadoğu'nun iki bölgesel gücü olan İran ve Türkiye arasındaki ekonomik ilişkiler, 2000'li yıllara kadar oldukça düşük seviyede kalmış ve özellikle siyasi ilişkilere bağımlı olarak değişkenlik göstermiştir.

1980 yılında başlayan ve 8 yıl süren İran-Irak Savaşı boyunca iki ülke için de stratejik önemi artan Türkiye, savaşta taraf olmayıp pragmatist bir politika izleyerek bu ülkelerle ekonomik ilişkilerini geliştirmiştir. Örneğin Türkiye ve İran arasında 1983 ve 1984 yıllarında gerçekleşen 2,3 milyar dolar ticaret hacmi ile iki ülke arasındaki ticarette rekor kırılmıştır. Ancak 1980'lerin ikinci yarısından itibaren hem düşen petrol fiyatlarının Ortadoğu ekonomilerini yavaşlatması hem de savaşın bitmesi ticaret hacmini savaş öncesi seviye inmesine neden olmuştur. ${ }^{27}$ İki ülke arasındaki ekonomik ilişkiler 1990'lardan sonra ise siyasi ilişkilere bağımlı olarak oldukça kötü gelişmiştir. 1990'lara doğru düşmeye başlayan iki ülke arasındaki ticaret hacmi şekilde de görüleceği üzere 2000 yılına kadar sadece 1996 yılında 1 milyar doların üzerinde gerçekleşmiş, diğer yıllar bu rakamın altında kalmıştır. ${ }^{28}$

26 World Bank Overview, İran, http://www.worldbank.org/en/country/iran/overview, 01.01.2015

27 Mustafa Aydın, Damla Aras, Ortadoğu'da Ekonomik İlişkilerin Siyasi Çerçevesi; Türkiye'nin İran, Irak ve Suriye ile Bağlantıları, Uluslararası İlişkiler Dergisi, Cilt 1, Say1 2, 2004 Yaz, s. 108

28 Mustafa Aydın, Damla Aras, s. 111 
Şekil 2: Y1llar İtibariyle Türkiye'nin İran ile İhracat ve İthalat

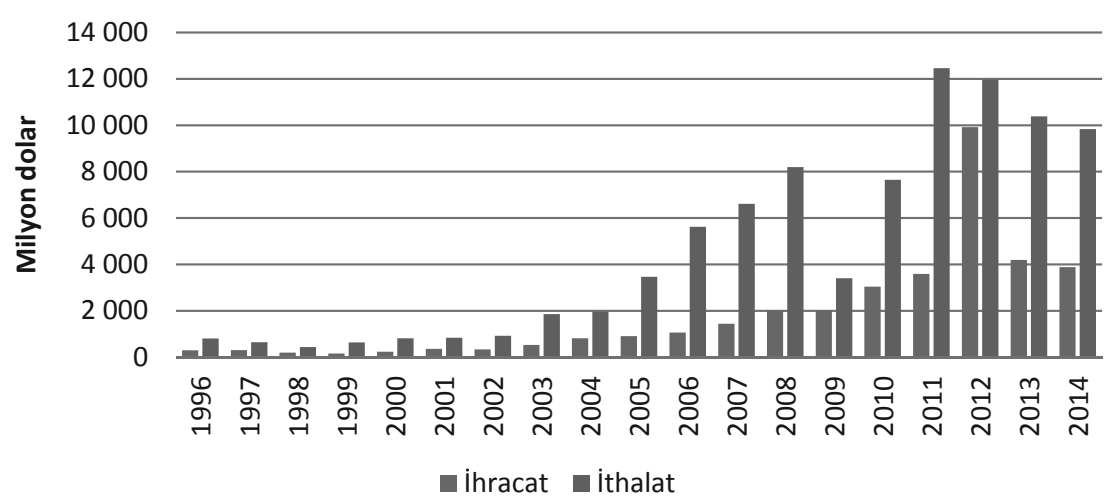

Kaynak: TÜIK

2002 y1lından 2009 y1lındaki küresel krize kadar sürekli artan iki ülke arasındaki ticaret hacmi tarihin en yüksek seviyelerine çıkmıştır. Her ne kadar son birkaç yıl ambargoların baskısına karşı konulabilse de İran'a karşı artan baskı 2013 yılında Türkiye-İran ekonomik ilişkilerini de olumsuz etkilemiştir. 2012 yılında 21,8 milyar dolar olan iki ülke arasındaki ticaret hacmi sonraki iki y1lda düşüş göstermiş ve 2013'de 14,5 milyar dolar, 2014 'te ise 13,7 milyar dolar olarak gerçekleşmiştir. ${ }^{29}$

İki ülkenin birbirleri için ticari olarak önemlerine bakıldığında ise; 1996 y1lında Türkiye'nin toplam ticaret hacminde \%1,3 olan İran'ın payı, 2002 y1lından itibaren artmaya başlamış ve 2006 yılında 2,6 olarak gerçekleşmiştir. 2011 y1lında \%4,6 ve 2012 y1lında \%5,6 ile en yüksek seviyelere ulaştıktan sonra 2013 yılı 3,6 ve 2014 yılında \%3,4 olarak gerçekleşmiştir. İran'ın toplam ticaretinde Türkiye'nin payı ise 2010 yılına kadar \% 5'in altında iken 2010 yılı ile birlikte artmaya başlamış ve yaptırımların ağırlaştı̆g 2012 y1lında \%16 ve 2013 y1lında ise \% 13 olarak gerçekleşmiştir.

Türkiye ve İran gibi rekabet ve çatışmalarla dolu bir geçmişe ve benzer demografik büyüklüğe sahip olan Fransa ve Almanya arasındaki ticaret hacmine ve iki ülkenin birbirleri için ekonomik önemlerine bakıldığında Tür-

29 http://www.dunya.com/ambargo-turkiye-iran-ticaretini-vurdu-148954h.htm, Erişim Tarihi: 25.06 .2014 
kiye ve İran arasındaki ticaret hacminin potansiyelinin çok altında olduğu görülmektedir. ${ }^{30} 2014$ yılında Almanya'nın ihracatında 102 milyar euro ile birinci surada yer alan Fransa, ithalatında ise 88 milyar euro ile yine üçüncü sırada yer almaktadır. ${ }^{31}$ Fransa'nın ihracatında ise Almanya \%16,6 ile ve ithalatında $\% 17,1$ ile birinci sırada yer almaktadır. ${ }^{32}$ Elbette ki Fransa ve Almanya gibi gelişmiş ekonomiler ile Türkiye ve İran'ı karşılaştırmak doğru olmaz ancak burada konu olan rakamlar iki ülke arasındaki ticaret hacminden çok iki ülkenin birbirleri için ekonomik önemidir. Türkiye ve İran'ın birbirlerinin ticaretindeki yerine bakıldığında; Türkiye'nin ihracatında İran sadece geçtiğimiz üç yılda ilk 10'a girebilmiş, ithalatında ise son 5 yılda altıncı olurken daha önceki yıllarda bu seviyeye çıkamamıştır. İran'ın ihracatında ve ithalatında Türkiye ilk 5'de yer alsa da İran'ın ticaret partnerleri içinde Çin ve Hindistan'ın yüksek oranlarda ilk sıralarda yer aldığını ve Türkiye'nin bu ülkelerden sonra geldiğini vurgulamak gerekir. ${ }^{33}$

Bununla birlikte iki ülke arasında karşılıklı ekonomik bağımlılığı artıracak karşılıklı sermaye yatırımlarına bakıldığında daha düşük rakamlarla karşılaşılmaktadır. Türkiye ekonomisinin son 10 yılda yakaladığı ekonomik performansta önemli bir yeri olan doğrudan yabancı sermaye yatırımlarının içinde İran sermayesinin payı \%1'in altında kalırken Türk iş adamlarının en çok tercih ettiği ülkeler arasına İran girmemektedir. ${ }^{34}$

Türkiye-İran ekonomik ilişkilerinin yapısına bakıldığında en dikkat çeken noktanın iki ülke arasındaki ticari dengenin büyük oranda Türkiye aleyhinde olduğudur. İkinci şekilde de görüldüğü gibi Türkiye'nin İran ile olan ticaretinde her yıl açık vermektedir. Bu dengesizliğin sebebi ise Türkiye'nin İran'dan ithal ettiği yüksek miktarlarda petrol ve doğalgazdır.

30 Kemal İnat, Türkiye'nin Son Dönemdeki İran Politikası: Barış ve Kalkınma için Karşılıklı Bağımlılık, Ortadoğu Analiz, 2009, cilt 1, sayı 10, s. 15

31 Destatis Statistics Bundesamt, www.destatis.de/EN/FactsFigures/National Economy Environment/ForeignTrade/ForeignTrade.html, 05.05.2015

$32 \mathrm{http}: /$ www.alphainternationaltrade.com/en/choose-your-markets/country-profiles/ france/trade-profile, http://www.alphainternationaltrade.com/en/choose-your-markets/ country-profiles/france/trade-profile

33 Kemal İnat, Türkiye'nin Son Dönemdeki İran Politikası: Barış ve Kalkınma için Karşılıklı Bağımlılık, Ortadoğu Analiz, 2009, cilt 1, sayı 10, s. 15

34 http://www.bugun.com.tr/ekonomi/turklerin-yurtdisi-yatirimi-artti-haberi/1239836, 15.05.2015 
Türkiye'nin yüksek ekonomik büyüme rakamları yakalamaya başladığı 2003 yılının ardından artan petrol, doğalgaz ve üretimini büyük oranda doğalgazla sağladığı elektrik enerjisine olan talebin artması Türkiye'nin enerji ithalatının da hızlı bir şekilde artmasına neden olmuştur. Bu durum dünyanın en zengin petrol ve doğalgaz rezervlerine sahip ülkelerinden biri olan İran ile Türkiye'nin ilişkilerinde de kendini göstermiştir.

Şekil 3: Türkiye'nin İran'dan yaptığı ithalatta mineral yakıtların yeri

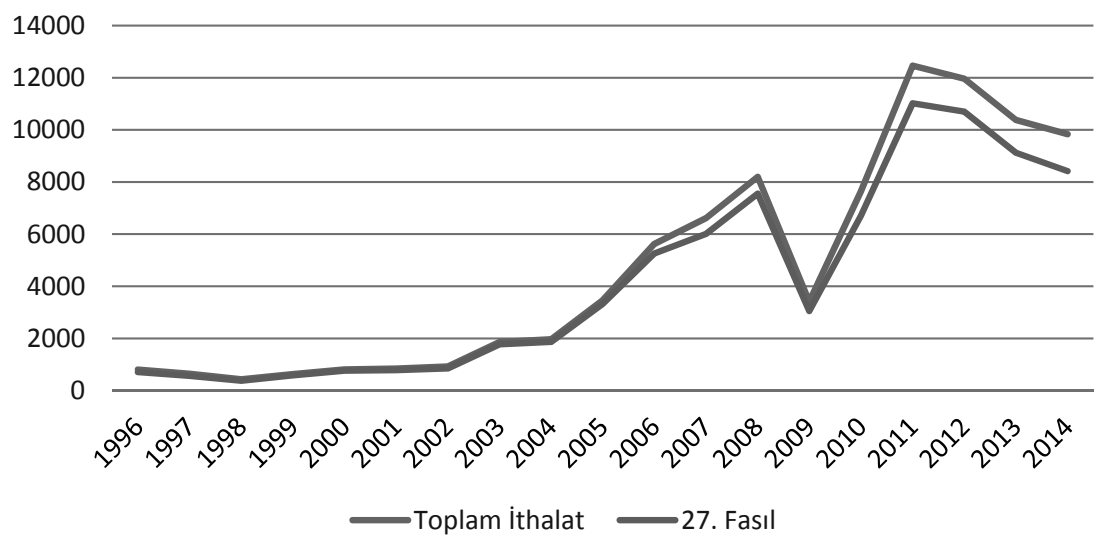

Kaynak: TÜIK

Şekilde de görüleceği üzere Türkiye'nin İran'dan yaptığı toplam ithalatın çok yüksek bir oranını dış ticarette 27. Fasıl olarak tanımlanan ve içinde petrol, petrol ürünleri ve doğalgazın da olduğu kalem kaplamaktadır. Enerji ithalatının bu kadar yüksek oranlarda olması iki ülke arasındaki toplam ticaret hacminde de görünmektedir. 2009 yılında toplam ticaret hacminin \%56'sinı oluşturan enerji ithalatı 2010 'da \%64, 2011'de \%68, 2012 'de \%48, 2013 y1lında \%44'ünü ve 2014 y1lında ise \%61'ini oluşturmaktadır oluşturmuştur. 2013 yılında Türkiye'nin İran'dan yaptığı 10,3 milyar doları ithalatın 9,1 milyar doları mineral yakıtlardan oluşurken son beş yılda yaptığı ithalatın \% 88'i mineral yakıtlardan oluşmuştur. 2012 y1lındaki büyük değişikliğin sebebinin ise İran'ın nükleer faaliyetlerinden dolayı başlatılan yaptırımlar nedeniyle Türkiye'nin enerji ithalatı karşı11- 
ğındaki borcunu yüksek miktarda altın ihracatı yaparak karşılamasından kaynaklandığını belirtmek gerekir. Bununla Türkiye'nin İran'dan yaptığı petrol ve doğalgaz ithalatının iç talebi karşılamada önemli bir yeri vardır. Türkiye'nin son 10 yılda petrol ithalatında en çok başvurduğu ülke İran olurken doğalgaz ithalatında \%19 ile İran, Rusya'dan sonra Türkiye'nin ikinci büyük kaynak ülkesidir.*

İki ülke arasındaki ihracata Türkiye tarafindan bakıldığında ise Türkiye'nin İran'a ihracatı İran'ın toplam ithalatının \% 19'una karşıllık gelen kıymetli taş ve demir çelik kalemlerinden oluşmaktadır. Bunun yanında makine ve cihazlar, elektronik eşyalar ve plastik mamuller Türkiye'nin İran'a yaptığı ihracata konu olan diğer mallardır. ${ }^{35}$

İki ülke ticaretinin bu rakamlara ulaşmasında önemli bir yeri olan enerjinin Türkiye ve İran ilişkilerinin hatta iki ülkenin enerji jeopolitiği açısından sahip oldukları önemi artıracak başka bir potansiyelleri vardır. $\mathrm{Bu}$ da İran'ın dünyanın en zengin doğalgaz rezervlerine sahip ülkelerden biri olması Türkiye'nin ise doğalgazda kaynak çeşitliliği yaşayan $\mathrm{AB}$ ülkelerine köprü konumunda olmasıdır. Türkiye ve İran'ın enerji konusunda iş birliğine gitmeleri yani; İran'ın sahip olduğu bu zenginliklerin Türkiye üzerinden Avrupa'ya taşınması iki ülke ilişkilerini daha farklı bir konuma taşıyacaktır. Bu durumun farkında olan iki ülke yönetimleri bu amaçla adımlar atmış ancak gelinen noktada hem İran'a karşı ABD ve AB'nin uyguladığ yaptırımlar hem de İran'ın politikaları bu potansiyelin ortaya konulmasını engellemektedir.

2013 yılı sonu itibariyle dünyanın en zengin dördüncü petrol rezervine ve dünyanın en zengin doğalgaz rezervlerine sahip olan İran yatırım eksikliğinden dolayı bu rezervlerden potansiyeli ölçüsünde faydalanamamaktadır. Halen dünyanın en önemli petrol ihracatçılarından biri olmasına rağmen İslam Devrimi öncesinde 208 milyon tona kadar çıkan yıllık petrol üretimi, İslam Devrimi sonrası uygulanmaya başlayan yaptırımlar, İranIrak Savaşının verdiği zararlar ve son yıllarda da nükleer faaliyetlerinden dolayı karşı karşıya olduğu yaptırımlar nedeniyle bu seviyeyi yakalayama-

35 *Rakamlar TPAO ve EPDK'nın sektör raporlarından alınmıştır.

Ekonomik Bakanlığ1, http://www.ekonomi.gov.tr/upload/B1414890-BF60-34F4-63D 8B6621011EDAD/TAHRAN.pdf, Erişim tarihi: 14.07.2014 
mıştır. ${ }^{36}$ Doğalgaz üretiminde ise yatırım eksikliğinin yarattığı sonuç çok daha çarpıcıdır. Zira belirtildiği gibi dünyanın en zengin rezervlerine sahip olan İran önemli bir gaz ihracatçısı olmaktan çok uzaktır. Her ne kadar ortaya çıkan bu sonuçta iç tüketiminin fazla olmasının katkısı olsa da rezervleriyle karşılaştığında İran'ın doğalgaz üretimi çok düşük kalmaktadır. Yatırım eksikliğine çözüm olarak yabancı arama şirketlerini ülkesine davet eden İran, arama ve üretim şirketleri için önemli bir üretim sahasıdır. ${ }^{37}$ $\mathrm{Bu}$ durum aynı zamanda TPAO'nun yurt dışı üretimini artırmayı hedefleyen Türkiye için İran'la arasındaki karşılıklı bağımlılığı yaratmak için bir alan yaratmaktadır. Ancak Azerbaycan ve Kazakistan gibi ülkelerde arama ve üretim faaliyetleri yürüterek üretimini ve etkinliğini artırmaya çalışan TPAO, İran pazarına girememektedir. İran'ın bu konuda hem TPAO'ya hem de Som Petrol gibi Türk şirketlere gösterdiği tavır İran'ın bu konuda Türkiye'ye bağımlı olmak istememesinin bir göstergesidir. 2007 yılında İran ve Türkiye arasında imzalanan doğalgaz mutabakat zaptı anlaşmasına göre TPAO, İran'ın en zengin doğalgaz sahası olan Güney Pars'taki 3 alanda üretim yapacak ve bu üretimi iki ülke paylaşacaktı. ${ }^{38}$ TPAO 2009 yılında faaliyetlere başladı ancak mutabakat zaptının anlaşmaya dönüşememesi nedeniyle faaliyetlerine devam edemedi. Benzer şekilde İran'da enerji alt yapısının inşası üzerine alt yapı faaliyetlerinde bulunan Som Petrol üretim faaliyetlerine ise İran bürokrasinin çıkardığı engeller nedeniyle girememektedir. ${ }^{39}$ Oysa Çin'den Sinopec, Rusya'dan Gazprom ve Japonya'dan Inpex gibi şirketler İran'ın önemli petrol sahalarında üretim faaliyetlerini sürdürebilmektedir. Bu şirketlerin yanı sıra İran'ın nükleer faaliyetleri nedeniyle başlatılan yaptırımlardan önce Batılı şirketler de İran' da arama ve üretim faaliyetlerine katılabiliyorlard $1{ }^{40}$

Doğu-Batı hattında enerji koridoru olarak hem kendi enerji ihtiyacını garanti altına almaya hem de enerji jeopolitiği açısından önemini artırmaya

36 http://www.al-monitor.com/pulse/originals/2014/02/iran-oil-contract-sanctionsenergy-nuclear.html\#, http://www.energyglobal.com/news/drilling-and-production/art icles/Iranian-oil-gas-sector-EIA.aspx\#.U91oh_1_te8, Erişim tarihi: 26.07.2014

37 EIA, Country Profile Iran, İstatistikler BP Statistical Review World of Energy 2014'ten alınmıştır.

38 Elin Kinnander, The Turkish-Iranian Gas Relationship: Politically Succesful, Commercially Problematic, Oxford Energy Institute, 2010, s. 11

$39 \mathrm{http} / /$ uk.reuters.com/article/2010/07/23/turkey-iran-sompetrol-idINANK00293820100723, Erişim Tarihi: 27.06.2014

40 EIA, Country Profile Iran 
çalışan Türkiye'nin, Azerbaycan ve Hazar havzasındaki doğalgaz rezervlerini taşıma konusunda kaydettiği ilerlemeler bu konuda tarafların kararlığını gösterir niteliktedir. Ancak İran'ın doğalgaz zenginliğinin Türkiye üzerinden taşınması uzun yıllardır gündeme gelmesine rağmen imzalanan ancak anlaşmaya dönüşemeyen mutabakat zaptlarından öteye gitmemektedir. Bu sonucun ortaya çıkmasında her ne kadar yaptırımların önemli bir payı olsa da İran'ın Türkiye ile işbirliği yapma hususunda gösterdiği isteksizlik ilerleme kaydedilmesini engellemektedir.

İki ülke arasındaki karşılıklı yatırımların az olması, bürokratik engeller ve enerji iş birliği gibi önemli konularda karşılaşılan zorluklar, Türkiye ve İran arasında bölgesel rekabetten ve geçmişteki ilişkilerden kaynaklanan çekinceler iki ülke ilişkilerinin daha ileri boyutlara taşınmasını zorlaştırmaktadır.

\section{Karşılıklı Ekonomik Bağımlılık ve Türkiye-İran ilişkileri}

İki ülke arasındaki ticaret geçtiğimiz 10 yılda tarihinin en yüksek seviyelerine çıksa da vazgeçilmez maliyetler doğuran, kırılganlığ ya da duyarlılığ artıran seviyelere ulaşmamıştır. İlk olarak Türkiye'nin toplam ticaretinde İran'ın önemine bakıldığında; Türkiye'nin ihracatı 1996 yılında 297 milyon dolar seviyesinden 2014 yılında gelindiğinde 3,8 milyar dolara çımıştır. Ancak Türkiye'nin ihracat yaptığ 1 ülkeler sıralamasında 10. sırada yer almaktadır ve bu rakam Türkiye'nin ihracatının sadece $\% 2,4$ 'ünü oluşturmaktadır. Bununla birlikte Türkiye'nin ihracatına konu olan malların içinde plastik mamuller, kazan, makine ve cihazlar önemli bir yer kaplamaktadır. Dolayısıyla bu mal akışının durması İran açısından önemli bir maliyet ya da kırılganlık doğurmamaktadır. Türkiye'nin İran'dan yaptığ ithalatta ise petrol ve doğalgaz yaklaşık \%90 oranında bir ağırlığa sahiptir. Türkiye'nin geçtiğimiz yıl 10 farklı ülkeden petrol ithalatı yaptığı düşünüldüğünde petrol kaynağ1 konusunda yeterli çeşitliliğe sahip olduğu görülmektedir. Her ne kadar doğalgaz tedariki konusunda kaynak çeşitliliği sorunu yaşasa da geçtiğimiz yıllarda İran'dan gönderilen doğalgazın kesilmesi durumunda Türkiye bunu Rusya'dan aldığı doğalgazla dengelemeyi başarmıştır.

Bununla birlikte iki ülke ekonomik ilişkilerinde önemli bir rol üstlenebilme potansiyeli olan şirketlerin karşılıklı yatırımlarına bakıldığında; iki 
ülke ilişkilerini yönlendirebilecek seviyede bir sermaye akışından söz edilemez. Yukarıda da bahsedildiği üzere Türkiye'ye gelen yabancı sermaye içinde İran kaynaklı sermayenin oranı \% 1'i bile geçmezken, Türk iş adamlarının hali hazırda 32 milyar dolarlık yurt dışı yatırımlarının içinde İran ilk sıralarda değildir. ${ }^{41}$

Türkiye ve İran arasındaki ekonomik ilişkilerin karşılıklı bağımlılık yaratacak bir seviyeye ulaşması için her şeyden önce iki ülke arasındaki ticaret hacminin daha da artması ve bunun yanında bu ticarete konu olan malların çeşitlendirilmesi gerekmektedir. Fransa ve Almanya örneğinde olduğu gibi gelişmiş ülkelerin birbirleriyle ticaretine bakıldığında ülkeler arası ticaretin siyasi ve ekonomik ilişkilerdeki etkisinin önemi görünmektedir. ${ }^{42}$

İki ülke arasındaki ticaretin artırılmasının yanı sıra iki ülkeyi adeta birbirine bağlayacak ve siyasi ilişkileri de yönlendirebilecek olan 2007 yılındaki doğalgaz mutabakat anlaşmasının hayata geçirilmesi gerekmektedir. İran'dan çıkarılacak olan doğalgazın Türkiye üzerinden Avrupa'ya taşınması Türkiye ve İran ilişkilerini ekonomik ilişkileri kadar etkileyebilecek bir gelişme olacaktır.

\section{Sonuç}

1990'lı yıllar boyunca PKK'nın silahlı eylemleri ve Siyasal İslam'ın yükselişi nedeniyle Türkiye'nin güvenlik sorunları yaşaması dış politikasını da şekillendirmiştir. Bu faktörlerin yurt dışından destek aldığ düşüncesi Türkiye'nin İran dâhil komşularıyla problemli yıllar geçirmesine neden olmuştur. 28 Şubat post-modern darbesinin ardından İslamcıların siyasetten tasfiyesi ve askeri operasyonlarla PKK'ya vurulan darbeler 2000'li yıllarda Türk Dış Politikasının evirilmesine zemin hazırlamıştır. Türk Dış Politikasının dönüşümüne etki eden bir başka faktör ise 2001 yılında yaşanan ekonomik krizin ardından Türkiye'nin liberal ekonomi politikaları uygulamaya başlaması ve dış ticarete daha fazla önem vermesi olmuştur.

Yaşanan bu sürecin ardından 2002 yılında tek başına iktidara gelen AK Parti, geçmişte tek başına iktidara gelen hükümetler gibi daha hızlı hareket edebilmiş ve hem ekonomideki hem de diş politikadaki dönüşüm

${ }^{41}$ http://www.hurriyet.com.tr/ekonomi/20406472.asp, 15.05.2015

42 Kemal İnat, a.g.y. 
hızlanmıştır. Yeni hükümetin dış politika yapıcılarının "komşularla sıfır sorun" olarak adlandırdığı politika sayesinde 1990'lı yıllar boyunca krizlerle geçen komşuluk ilişkileri gelişmeye başlamıştır. Komşularıyla ilişkilerini daha sağlam bir zemine oturtmayı isteyen Türkiye, dış politikasında ekonomik araçları daha fazla kullanarak karşılıklı ekonomik bağımlılık ilişkisine dayalı ilişkiler kurmayı hedeflemiştir. Ekonomide kendini istatistiklerle gösteren bu durum siyasal alanda da karşılıklı ziyaretler ve demeçlerde göstermiştir.

Bu politikalar çerçevesinde Türkiye ve İran arasındaki ekonomik ilişkiler tarihinin en iyi dönemini yaşamıştır. Ancak her ne kadar iki ülke arasındaki ekonomik ilişkileri gelişse de ülkelerin birbirleri için ekonomik önemine, ticarete konu olan mallara ve ülkeler arası sermaye akışlarına bakıldığında herhangi bir karşılıklı bağımlılık ilişkisinin olmadığı görülmektedir. Dolayısıyla Türk Dış Politikasının İran ile arasında karşılıklı ekonomik bağıml1lık yaratma hedefi gerçekleşememiştir. İki ülke arasında kökü geçmişe dayanan bölgesel rekabet, bürokratik engeller ve karşılıklı algı bozuklukları ekonomik ilişkilerin sahip olduğu potansiyelinin altında kalmasına neden olmaktadır.

\section{Kaynakça}

Aydın Mustafa, Damla Aras, "Ortadoğu'da Ekonomik İlişkilerin Siyasi Çerçevesi; Türkiye'nin İran, Irak ve Suriye ile Bağlantıları”, Uluslararası İlişkiler Dergisi, Cilt 1, Sayı 2, 2004, ss. 103-128.

Burchill, Scott; Linklater, Andrew ve diğerleri, Uluslararası İlişkiler Teorileri, Çev. Ali Aslan, M. Ali Ağcan, Küre Yay. 2.Baskı, İstanbul 2013.

Davutoğlu, Ahmet, Stratejik Derinlik, Küre Yayınları, 35. Bask1, İstanbul 2009.

İnat, Kemal, “Türkiye'nin Son Dönemdeki İran Politikası: Barış ve Kalkınma için Karşılıklı Bağımlılık”, Ortadoğu Analiz, 2009, cilt 1, sayı 10, ss. 7-16.

Kirişçi, Kemal, "The Transformation of the Turkish Foreign Policy: The Rise of the Trading State", New Perspectives on Turkey, no.40, 2009, ss. 29-57. 
Kutlay, Mustafa, "Yeni Türk Dış Politikasının Ekonomi Politiği: Eleştirel Bir Yaklaşım”, Uluslararası İlişkiler Dergisi, cilt 9, say 35, Güz 2012, ss. 101-127.

Kutlay, Mustafa, Osman Bahadır Dinçer, “Türkiye'nin Ortadoğu'daki Bölgesel Güç Potansiyeline İlişkin Ampirik Bir İnceleme”, Akademik Ortadoğu, Vol. 6, No. 2, 2012, ss. 61-97.

MÜSİAD, Araştırma Raporları, Yükselen Değer Türkiye, İstanbul 2010.

Nye, Joseph S., Robert O. Keohane, "Transnational Relations and World Politics: An Introduction, International Organization", vol. 25, no. 3, s. 332, pp. 329-349.

Renda, Kadri Kaan, “Turkey's Neighborhood Policy: An Emerging Complex Interdependence?”, Insight Turkey, vol.13, no.1, 2014, ss. 89-108.

Robert O. Keohane, Joseph S. Nye, Power and Interdependence, 2. Bask1, Tbs, 1989.

Sarıaslan, Fatma, “2000’li Yıllarda Türkiye-İran Ekonomik İlişkileri, Akademik Ortadoğu Dergisi”, Say1 14, İstanbul, ss. 65-91.

Sinkaya, Bayram, "Rationalization of Turkey-Iran Relations: Prospects and Limits", Insight Turkey, vol. 14, no. 2, 2012, pp. 137-156.

\section{Internet Kaynaklart}

Destatis Statistics Bundesamt, www.destatis.de/EN/FactsFigures/Nationa1EconomyEnvironment/ForeignTrade/ForeignTrade.html, Erişim Tarihi: 05.05.2015.

http://www.alphainternationaltrade.com/en/choose-your-markets/countryprofiles/france/trade-profile, Erişim Tarihi: 05.05.2015.

http://www.bugun.com.tr/ekonomi/turklerin-yurtdisi-yatirimi-artti-haberi/1239836, 15.05.2015.

http://www.hurriyet.com.tr/ekonomi/20406472.asp, 15.05.2015.

World Bank Overview, İran, http://www.worldbank.org/en/country/iran/ overview, Erişim Tarihi: 01.01.2015.

http://www.dunya.com/ambargo-turkiye-iran-ticaretini-vurdu-148954h. htm, Erişim Tarihi: 25.06.2014. 
http://www.nytimes.com/2013/01/26/opinion/work-with-china-dontcontain-it.html?_r=0, Erişim tarihi: 15.10.2014.

http://www.usak.org.tr/dosyalar/rapor/5GMcs3mKfFPCbD08MCXSSs6sf dvvA7.pdf, Erişim Tarihi: 18.04.2014. 